\title{
Preventing and Managing Cardiometabolic Risk: The Logic for Intervention
}

\author{
Mark A. Pereira ${ }^{1}$, Thomas E. Kottke ${ }^{2,3, *}$, Courtney Jordan ${ }^{1}$, Patrick J. O'Connor ${ }^{2}$, \\ Nicolaas P. Pronk ${ }^{2,3}$ and Rita Carreón 4
}

1 Division of Epidemiology and Community Health, School of Public Health, University of Minnesota, Minneapolis, MN 55454-1015, USA; E-Mails: pereira@epi.umn.edu (M.A.P.); carr0172@umn.edu (C.J.)

2 HealthPartners Research Foundation, Minneapolis, MN 55440-1524, USA; E-Mails: Patrick.J.OConnor@HealthPartners.Com (P.J.O’C.); Nico.P.Pronk@HealthPartners.Com (N.P.P.)

3 JourneyWell, Minneapolis, MN 55425, USA

4 America's Health Insurance Plans, Washington, DC 20004, USA; E-Mail: rcarreon@ahip.org

* Author to whom correspondence should be addressed;

E-Mail: Thomas.e.kottke@healthpartners.com; Tel.: +1-612-580-0153; Fax: +1-952-967-5022.

Received: 10 August 2009 / Accepted: 29 September 2009 / Published: 30 September 2009

\begin{abstract}
Cardiometabolic risk (CMR), also known as metabolic syndrome or insulin resistance syndrome, comprises obesity (particularly central or abdominal obesity), high triglycerides, low HDL, elevated blood pressure, and elevated plasma glucose. Leading to death from diabetes, heart disease, and stroke, the root cause of CMR is inadequate physical activity, a Western diet identified primarily by low intake of fruits, vegetables, and whole grains, and high in saturated fat, as well as a number of yet-to-be-identified genetic factors. While the pathophysiological pathways related to CMR are complex, the universal need for adequate physical activity and a diet that emphasizes fruits and vegetables and whole grains, while minimizing food high in added sugars and saturated fat suggests that these behaviors are the appropriate focus of intervention.
\end{abstract}

Keywords: cardiometabolic risk; diet; physical activity; treatment; prevention; strategy 


\section{Cardiometabolic Risk: A Cluster of Risk Factors}

First described by Reaven in 1988 as "Syndrome-X" [1], the constellation of obesity (particularly central or abdominal obesity), high triglycerides, low high density lipoprotein (HDL), elevated blood pressure, and elevated plasma glucose has been variously described as "insulin resistance syndrome", "metabolic syndrome" and "cardiometabolic risk" (CMR). We use the latter term in this paper to describe the cluster of risk factors. Although the American Diabetes Association, the American Heart Association, and the National Heart, Lung, and Blood Institute at the National Institutes of Health do not recognize the group of risk factors as a syndrome, the organizations all acknowledge that the individual risk factors are causally related to diabetes, heart disease, stroke, and renal failure [2,3]. It is important to understand the origins of CMR and develop appropriate intervention strategies because CMR costs the United States nearly $\$ 500$ billion a year in health care and lost wages $[4,5]$ and is an emerging problem worldwide.

\section{CMR: The Association with Obesity}

Along the path from health to disease, abdominal obesity and insulin resistance are precursors to elevated blood glucose, dyslipidemia and, possibly, systemic inflammation and hypofibrinolysis [6-14]. When abdominal obesity is present, excess release of circulating free fatty acids and a variety of cytokines that may contribute to inflammation and/or oxidative stress, may cause or exacerbate peripheral insulin resistance [7,8,15-17]. Evidence from cross-sectional and longitudinal studies demonstrates higher risk of morbidity and mortality among individuals with disproportionately high visceral abdominal fat when accounting for total body weight or total body fat [17-19]. Indeed, there is evidence for an association of excess abdominal fat and chronic disease risk across a wide range of BMI values [20-22], and the prevalence of CMR begins to rise well below the cutoff for overweight status (BMI $25 \mathrm{~kg} / \mathrm{m}^{2}$ ) [21].

\section{CMR: The Association with Physical Inactivity}

The experimental evidence that exercise modulates insulin resistance and lowers risk factor levels for type 2 diabetes and cardiovascular disease is substantial [23-29]. Well-conducted experiments in men and women of varying race/ethnic groups have clearly demonstrated improvements in insulin sensitivity as a result of single exercise bouts or brief training periods with no change in body weight [24,25,27-37].

Although the precise mechanisms whereby physical activity may have a direct effect on insulin sensitivity are not completely understood, there appears to be support from animal and human studies for mechanisms that involve enhanced insulin receptor and post-receptor function, increased skeletal muscle insulin-sensitive glucose transporter proteins, increased skeletal muscle capillary density, and, over longer time periods, changes in body composition [38-51]. Some of these responses to exercise may also occur in the liver and adipose tissue [36]. Exercise also reduces levels of inflammatory markers, raises high density lipoprotein cholesterol (HDL) and lowers triglycerides. 
Through a variety of mechanisms, including those independent of energy balance and weight change, endurance training has been shown to reduce visceral abdominal fat deposition and improve insulin sensitivity [52-55]. Endurance training, such as brisk walking, has been shown to increase HDL [53]. Independent of weight loss, physical activity may reduce blood pressure through a variety of mechanisms, including an attenuation of adrenergic sympathetic activity and a reduction in total peripheral resistance $[25,56,57]$. Additionally, the reductions in hyperinsulinemia and abdominal fat associated with exercise may reduce blood pressure through decreased sodium retention and reduced sympathetic nervous system stimulation [58-61]. This strong negative association between physical activity and risk of coronary heart disease biologically underscore the plausible effects of physical activity on CMR [30,62].

\section{CMR: The Association with Dietary Factors}

As with exercise, the literature is rich with experimental evidence supporting direct effects of a variety of dietary components on insulin sensitivity and risk factors for cardiovascular disease and diabetes. The results appear to be independent of weight loss. Clinically important effects have appeared within four weeks of intervention in controlled studies [63-65]. It is clear from experimental and observational studies that intake of saturated and trans-fatty acids promote insulin resistance, whereas monounsaturated, polyunsaturated, and longer chain n-3 fatty acids appear to improve insulin sensitivity [66-69]. Evidence has emerged over the past decade from experimental studies that less refined and less-starchy carbohydrates, such as fresh fruit, whole grains, green leafy vegetables, nuts, legumes, in contrast to fruit juice, refined grains, and starchy vegetables, have direct and independent beneficial effects on both glucose and insulin metabolism [63,70-95]. Several studies have demonstrated, over the short term, that changing dietary composition without changing calories may improve insulin sensitivity [63,93-97]. There are many plausible physiological explanations for these observations including attenuation of postprandial glycemia, reduced demand for insulin, and direct effects of dietary constituents on beta cells and peripheral insulin receptors [75-81,84,98-103].

The dietary fatty acids that promote insulin sensitivity are the same as those that lower triglycerides and raise HDL. Conversely, low-fat diets that are high in low-quality carbohydrates lower HDL and raise triglycerides. Long-chain fatty acids, such as the n-3 (omega-3) fatty acids found in certain fish, nuts, and seeds, may reduce blood triglyceride concentrations [104-111]. Replacing dietary saturated fat with monounsaturated fat also improves blood lipid profiles [106,112-114]. Controlled feeding studies demonstrate that these dietary effects are independent of changes in body weight [104,112-118].

A diet rich in fruits, vegetables, whole grains, potassium, calcium, and magnesium, and low in sodium may also lower blood pressure [64,119,120]. Although not supported by all studies [121], evidence from observational studies suggests that systemic inflammation and hypofibrinolytic states, conditions known to cluster with the other components of CMR [10-13], can also be ameliorated by following a minimally processed plant-based diet and a physical activity program [81,82,122-124]. Recent cross sectional observations have suggested that certain dietary patterns, such as those including whole grains, fruits, vegetables, low-fat dairy products, and regular physical activity are 
inversely associated with the odds of having CMR [125-128]. Prospective observations also suggest that these dietary patterns are inversely associated with risk of developing CMR [82,126,129,130].

\section{CMR: The Evidence from Trials of Diet and Physical Activity}

The Oslo Diet and Exercise Study compared the independent and joint effects of diet and exercise (aerobic training three times per week) on changes in CMR among 219 adults [131,132]. The goal of the dietary intervention was weight control, increased fish intake, and decreased fat intake. The exercise intervention included supervised endurance exercise three times per week. The group that received both the diet and physical activity intervention appeared to experience the greatest improvement in risk factors over a one-year period despite weight loss that was modest and no greater than that experienced in the diet only group [131,132]. In fact, the average BMI at follow-up remained in the overweight range (above $25 \mathrm{~kg} / \mathrm{m}^{2}$ ). The correlations between changes in body weight and changes in insulin resistance and components of CMR were very weak [132].

Esposito et al. conducted a 2-year randomized trial of diet and exercise in 180 adults with CMR [133]. Although changes in activity and body weight (mean difference $=-2.8 \mathrm{~kg}, \mathrm{p}<0.001$ ) were modest over the 2-year intervention, the intervention group experienced significant improvements for all components of CMR. Based on regression analysis, these changes appeared to be largely independent of changes in weight. At the end of the trial, adjusted for weight changes, only 40 of the 90 intervention participants continued to have CMR, compared to 78 of the 90 control participants $(\mathrm{p}<0.001)$.

Four large-scale randomized trials — one of them being the U.S. Diabetes Prevention Program--have examined the effect of diet and exercise in preventing type 2 diabetes among adults with glucose intolerance and high risk for type 2 diabetes [134-137]. These trials were conducted in four different populations-Sweden, China, Finland, and the United States. All found that lifestyle intervention significantly reduced the incidence of type 2 diabetes. These risk reductions were $25 \%$ in the Chinese study and 50 to $60 \%$ in the other trials. Weight loss was relatively modest across these studies, with means from $-0.8 \%$ to $+1.7 \%$ in the control groups and $-1.8 \%$ to $-6.0 \%$ in the intervention groups.

If reduction in CMR were dependent on magnitude of weight loss, one would expect correlations between changes in body weight and changes in CMR to be at least moderate in strength. However, all studies showed only weak or no correlations between changes in weight and changes in CMR. The relative risk reduction observed in the U.S. Diabetes Prevention Program for the diet and exercise intervention compared to usual care was $\sim 55 \%$ with a mean weight loss of $\sim 6 \%$ [135]. The intervention from Sweden and Finland achieved half of the weight loss of the U.S. study, but the relative risks for the diet and exercise intervention compared with usual care in those studies was very similar to the U.S. study. These data from well-conducted randomized trials with precise measures support the hypothesis that the behavioral components themselves, improved diet and increased physical activity, are the primary etiological factors driving the reduction in CMR and risk of diabetes, and that body weight changes may not be required for risk reduction to occur. Even if weight loss is relatively unimportant in the management of CMR, it can be important for other reasons. The same lifestyle behaviors that minimize CMR can aid in preventing weight gain over the long term because physical activity and the diet that prevents CMR also improves energy balance. 
The data suggest that the emphasis in such interventions must include lifestyle changes for three reasons: 1) lifestyle changes have known direct effects on risk reduction through a variety of pathways, 2) while good nutrition and adequate physical activity have many benefits in addition to weight control, attempts to lose weight through fasting or unbalanced diets can increase risk of untoward events without the benefits of physical activity or good nutrition, and 3) diet and physical activity are behaviors that are under the direct and immediate control of the individual.

\section{CMR: Policy Questions}

\subsection{Are Universal Precautions Warranted?}

One decision that must be made when designing an intervention program is whether and to what extent to focus on individuals with a particular set of physiological attributes (e.g., weight, BMI, waisthip ratio, girth, blood pressure, dyslipidemia, and plasma glucose) or to cast a broader net by assessing dietary patterns and physical activity levels for all individuals.

Focusing on physiological parameters is specific and identifies individuals who already have CMR. These individuals are highly likely to go on to develop the complications of CMR - diabetes and cardiovascular disease - and clinical trial evidence demonstrates that, after two years, moderate changes in diet and physical activity levels result in substantial and durable changes in CMR along with an average weight loss of $3 \%$ to $6 \%$ [138]. However, correction of the physiological abnormalities, and in particular, changing the behaviors that generated CMR in the first place can be expected to be challenging and evidence is equivocal that interventions delivered in a physician's office result in behavior change [139,140].

On the other hand, a universal lifestyle recommendation for entire communities or populations has been highly successful in some, but not all, instances [141]. Because the majority of Americans already have insulin resistance along with other risk factors [21], most individuals will benefit from responding to a universal recommendation to remain physically active and adopt a diet that is low in saturated fat and high in fruits and vegetables. Interventions delivered over the internet [142] and interventions delivered through the work site [143] have been successful, perhaps because both can increase the reach of the intervention and the frequency with which behavior change support can be delivered.

Fortunately, one strategy doesn't preclude another, and many organizations endorse the implementation of both strategies simultaneously. The American Heart Association and the National Heart, Lung and Blood Institute jointly state that the "prime emphasis in management of the metabolic syndrome per se is to mitigate the modifiable, underlying risk factors (obesity, physical inactivity, and atherogenic diet) through lifestyle changes [3], and the American Diabetes Association and the European Association for the Study of Diabetes jointly advise that "clinicians should neither rely on, nor require a diagnosis of, metabolic syndrome to prescribe and encourage what is now a fundamental tenet of medicine--weight maintenance (or reduction), exercise, and a healthy meal plan" [144].

A strategy that combines clinical intervention for those at high risk with a universal message of diet and physical activity for everyone could have a large immediate impact on disease rates while potentially shutting down the CMR pipeline. For example, a comprehensive program to prevent and 
treat heart disease in Finland resulted in a $63 \%$ decline in coronary heart disease mortality rates over a 15-year period with concomitant decreases in all-cause mortality and increases in life expectancy [141].

\subsection{What and How much should be Measured?}

A second decision that must be made is the number of screening tests that are performed to characterize CMR in individuals. Because measurement consumes resources that might be used for intervention, program planners must carefully consider this question. Although the pathophysiologic pathways of CMR are complex, neither the assessment tools nor the interventions need to be. Regardless of the intensity of assessment of the individual, prediction of when a particular individual will develop diabetes, heart disease or a stroke remains poor. On the other hand, the presence of the behaviors that convey CMR reduce life expectancy by about 10 years [145], and when smoking and excessive alcohol consumption are added to the risk function, the difference in life expectancy between a low risk and a high risk lifestyle is 14 years [146].

Some physiological components of CMR — weight, height, girth, blood pressure, HDL, triglycerides and glucose - are easily measured at point of care in the clinical setting or by the clinical lab. On the other hand, insulin resistance is not easily measured outside of the research setting. Measuring inflammatory status with high sensitivity C-reactive protein (hs-CRP) conveys little information when other risk factors are taken into account $[147,148]$, and a recent consensus statement from several organizations, including the American Diabetes Association concluded that measuring waist circumference contributes little to the clinical assessment of CMR [149]. Whatever other parameters are assessed, habitual diet and physical activity must be assessed, and they can be assessed with simple checklists [150]. If these tools are used, patients can be provided with immediate feedback and cues to action. A survey of health insurance plans in the United States documents that many health plans are positioned to deliver these behavioral support services [151].

\section{Conclusions}

CMR arises from the constellation of obesity (particularly central or abdominal obesity), high triglycerides, low HDL, elevated blood pressure, and elevated plasma glucose. The mechanism of action appears to be a pathway that starts with a behavior pattern of inadequate physical activity and a diet high in saturated fat and added sugars, and inadequate in fruits, vegetables, and whole grains. These behaviors lead to insulin resistance as an intermediate state. Insulin resistance, appearing even within the "normal" range of BMI $\left(<25 \mathrm{~kg} / \mathrm{m}^{2}\right)$, leads to the other risk factors in the cluster. These risk factors cause type 2 diabetes mellitus and cardiovascular disease. While maintaining or resuming ideal weight is beneficial for many reasons, experimental evidence demonstrates that improving diet and increasing physical activity reduces CMR independent of the degree of weight loss. These observations, and the fact that individuals can act directly to change their diet and increase their physical activity, suggest that the most effective intervention strategy to prevent and treat CMR is a universal intervention focusing on a healthy diet, adequate physical activity, and prevention of weight gain in adults and excess weight gain in youth. 


\section{Acknowledgements}

Financial support for the preparation of this report was provided by an unrestricted grant from sanofi-aventis to America's Health Insurance Plans (AHIP). sanofi-aventis did not have input into any phase of the data interpretation or the preparation of the manuscript.

\section{Reference}

1. Reaven, G.M. Syndrome X: 6 years later. J. Intern. Med. Suppl. 1994, 736, 13-22.

2. Eckel, R.H.; Kahn, R.; Robertson, R.M.; Rizza, R.A. Preventing cardiovascular disease and diabetes: a call to action from the American Diabetes Association and the American Heart Association. Diabetes Care 2006, 29, 1697-1699.

3. Grundy, S.M.; Cleeman, J.I.; Daniels, S.R.; Donato, K.A.; Eckel, R.H.; Franklin, B.A.; Gordon, D.J.; Krauss, R.M.; Savage, P.J.; Smith, S.C., Jr,; Spertus, J.A.; Costa, F. Diagnosis and management of the metabolic syndrome. An American Heart Association/National Heart, Lung, and Blood Institute Scientific Statement. Executive summary. Cardiol. Rev. 2005, 13, 322-327.

4. American Heart Association. Heart Disease and Stroke Statistics-2007 Update; American Heart Association: Dallas, Texas, USA, 2007.

5. Hogan, P.; Dall, T.; Nikolov, P. Economic costs of diabetes in the US in 2002. Diabetes Care 2003, 26, 917-932.

6. Visscher, T.L.; Seidell, J.C. The public health impact of obesity. Annu. Rev. Public Health 2001, 22, 355-375.

7. Reaven, G.M. Syndrome X. Blood Press Suppl. 1992, 4, 13-16.

8. Reaven, G.M. Pathophysiology of insulin resistance in human disease. Physiol. Rev. 1995, 75, 473-486.

9. Reaven, G.M. Are insulin resistance and/or compensatory hyperinsulinemia involved in the etiology and clinical course of patients with hypertension? Int. J. Obes. Relat. Metab. Disord. 1995, 19, S2-5.

10. Ford, E.S. The metabolic syndrome and C-reactive protein, fibrinogen, and leukocyte count: findings from the Third National Health and Nutrition Examination Survey. Atherosclerosis 2003, 168, 351-358.

11. Festa, A.; D'Agostino, R., Jr.; Howard, G.; Mykkanen, L.; Tracy, R.P.; Haffner, S.M. Chronic subclinical inflammation as part of the insulin resistance syndrome: the Insulin Resistance Atherosclerosis Study (IRAS). Circulation 2000, 102, $42-47$.

12. Sakkinen, P.A.; Wahl, P.; Cushman, M.; Lewis, M.R.; Tracy, R.P. Clustering of procoagulation, inflammation, and fibrinolysis variables with metabolic factors in insulin resistance syndrome. Am. J. Epidemiol. 2000, 152, 897-907.

13. Tracy, R.P. Inflammation, the metabolic syndrome and cardiovascular risk. Int. J. Clin. Pract. Suppl. 2003, 134, 10-17.

14. Laaksonen, D.E.; Lakka, H.M.; Niskanen, L.K.; Kaplan, G.A.; Salonen, J.T.; Lakka, T.A. Metabolic syndrome and development of diabetes mellitus: application and validation of recently 
suggested definitions of the metabolic syndrome in a prospective cohort study. Am. J. Epidemiol. 2002, 156, 1070-1077.

15. Despres, J.P.; Moorjani, S.; Lupien, P.J.; Tremblay, A.; Nadeau, A.; Bouchard, C. Regional distribution of body fat, plasma lipoproteins, and cardiovascular disease. Arteriosclerosis 1990, 10, 497-511.

16. Sjostrom, C.D.; Lissner, L.; Sjostrom, L. Relationships between changes in body composition and changes in cardiovascular risk factors: the SOS Intervention Study. Swedish Obese Subjects. Obes. Res. 1997, 5, 519-530.

17. World Health Organization Obesity: Preventing and Managing the Global Epidemic. Report of a WHO Consultation of Obesity; Division of Noncommunicable Diseases, Programme of Nutrition Family and Reproductive Health: Geneva, Switzerland, 1997.

18. National Institutes of Health. Clinical guidelines on the identification, evaluation, and treatment of overweight and obesity in adults - the evidence report. Obes. Res. 1998, 6, 51S-209S.

19. Peiris, A.N.; Sothmann, M.S.; Hoffmann, R.G.; Hennes, M.I.; Wilson, C.R.; Gustafson, A.B.; Kissebah, A.H. Adiposity, fat distribution, and cardiovascular risk. Ann. Intern. Med. 1989, 110, 867-872.

20. Sjostrom, C.D.; Hakangard, A.C.; Lissner, L.; Sjostrom, L. Body compartment and subcutaneous adipose tissue distribution —risk factor patterns in obese subjects. Obes. Res. 1995, 3, 9-22.

21. St-Onge, M.P.; Janssen, I.; Heymsfield, S.B. Metabolic syndrome in normal—weight Americans: new definition of the metabolically obese, normal-weight individual. Diabetes Care 2004, 27, 2222-2228.

22. Wong, S.L.; Katzmarzyk, P.; Nichaman, M.Z.; Church, T.S.; Blair, S.N.; Ross, R. Cardiorespiratory fitness is associated with lower abdominal fat independent of body mass index. Med. Sci. Sports Exerc. 2004, 36, 286-291.

23. Folsom, A.R.; Pereira, M.A. Cardiovascular benefits of endurance exercise. In Olympic Encyclopedia of Sports Medicine \& Science: Endurance in Sport; 2nd ed.; Torg, J.S., Shephard, R., Eds.; Blackwell Science: Oxford, UK, 2000; pp. 688-707.

24. Kriska, A.M.; Blair, S.N.; Pereira, M.A. The potential role of physical activity in the prevention of non-insulin-dependent diabetes mellitus: The epidemiologic evidence. In Exercise and Sport Science Reviews; Hollozsy, J.O., Ed.; Williams \& Wilkins: Baltimore, MD, USA, 1994; pp. 121-143.

25. Tipton, C.M. Exercise, training and hypertension: an update. Exerc. Sport Sci. Rev. 1991, 19, 447-505.

26. US Department of Health and Human Services. Physical Activity and Health. A Report of the Surgeon General.; US Department of Health and Human Services. Centers for Disease Control and Prevention. National Center for Chronic Disease Prevention and Health Promotion: Atlanta, GA, US, 1996.

27. Hamdy, O.; Goodyear, L.J.; Horton, E.S. Diet and exercise in type 2 diabetes mellitus. Endocrinol. Metab. Clin. North Am. 2001, 30, 883-907.

28. Horton, E.S. Exercise and decreased risk of NIDDM. N. Engl. J. Med. 1991, 325, 196-198.

29. Wallberg-Henriksson, H.; Rincon, J.; Zierath, J.R. Exercise in the management of non-insulindependent diabetes mellitus. Sports Med. 1998, 25, 25-35. 
30. Folsom, A.R.; Pereira, M.A. Cardiovascular benefits of endurance exercise. In Olympic Encyclopedia of Sports Medicine \& Science: Endurance in Sport; 2nd ed.; Torg, J.S., Shephard, R., Ed.; Blackwell Science: Oxford, UK, 2000; pp. 688-707.

31. Services, U.S. D. o. H. a. H. Physical Activity and Health: A Report of the Surgeon General; Services, U.S. D. o. H. a. H.: Atlanta, GA, USA, 1996.

32. Saltin, B.; Lindgarde, F.; Houston, M.; Horlin, R.; Nygaard, E.; Gad, P. Physical training and glucose tolerance in middle-aged men with chemical diabetes. Diabetes 1979, 28, 30-32.

33. Ronnemaa, T.; Mattila, K.; Lehtonen, A.; Kallio, V. A controlled randomized study on the effect of long-term physical exercise on the metabolic control in type 2 diabetic patients. Acta Med. Scand. 1986, 220, 219-224.

34. Trovati, M.; Carta, Q.; Cavalot, F.; Vitali, S.; Banaudi, C.; Lucchina, P.G.; Fiocchi, F.; Emanuelli, G.; Lenti, G. Influence of physical training on blood glucose control, glucose tolerance, insulin secretion, and insulin action in non-insulin-dependent diabetic patients. Diabetes Care 1984, 7, 416-420.

35. Koivisto, V.A.; Yki-Jarvinen, H.; DeFronzo, R.A. Physical training and insulin sensitivity. Diabetes Metab. Rev. 1986, 1, 445-481.

36. Brown, M.D.; Moore, G.E.; Korytkowski, M.T.; McCole, S.D.; Hagberg, J.M. Improvement of insulin sensitivity by short-term exercise training in hypertensive African American women. Hypertension 1997, 30, 1549-1553.

37. Sigal, R.J.; Kenny, G.P.; Boule, N.G.; Wells, G.A.; Prud'homme, D.; Fortier, M.; Reid, R.D.; Tulloch, H.; Coyle, D.; Phillips, P.; Jennings, A.; Jaffey, J. Effects of aerobic training, resistance training, or both on glycemic control in type 2 diabetes: a randomized trial. Ann. Intern. Med. 2007, 147, 357-369.

38. Thorell, A.; Hirshman, M.F.; Nygren, J.; Jorfeldt, L.; Wojtaszewski, J.F.; Dufresne, S.D.; Horton, E.S.; Ljungqvist, O.; Goodyear, L.J. Exercise and insulin cause GLUT-4 translocation in human skeletal muscle. Am. J. Physiol. 1999, 277, E733-741.

39. Kennedy, J.W.; Hirshman, M.F.; Gervino, E.V.; Ocel, J.V.; Forse, R.A.; Hoenig, S.J.; Aronson, D.; Goodyear, L.J.; Horton, E.S. Acute exercise induces GLUT4 translocation in skeletal muscle of normal human subjects and subjects with type 2 diabetes. Diabetes 1999, 48, 1192-1197.

40. King, P.A.; Betts, J.J.; Horton, E.D.; Horton, E.S. Exercise, unlike insulin, promotes glucose transporter translocation in obese Zucker rat muscle. Am. J. Physiol. 1993, 265, R447-452.

41. Goodyear, L.J.; Hirshman, M.F.; Horton, E.S. Exercise-induced translocation of skeletal muscle glucose transporters. Am. J. Physiol. 1991, 261, E795-799.

42. Goodyear, L.J.; Hirshman, M.F.; Horton, E.D.; Knutson, S.M.; Wardzala, L.J.; Horton, E.S. Exercise training normalizes glucose metabolism in a rat model of impaired glucose tolerance. Metabolism 1991, 40, 455-464.

43. Goodyear, L.J.; Hirshman, M.F.; King, P.A.; Horton, E.D.; Thompson, C.M.; Horton, E.S. Skeletal muscle plasma membrane glucose transport and glucose transporters after exercise. $J$. Appl. Physiol. 1990, 68, 193-198.

44. Hirshman, M.F.; Wardzala, L.J.; Goodyear, L.J.; Fuller, S.P.; Horton, E.D.; Horton, E.S. Exercise training increases the number of glucose transporters in rat adipose cells. Am. J. Physiol. 1989, 257, E520-530. 
45. Hirshman, M.F.; Wallberg-Henriksson, H.; Wardzala, L.J.; Horton, E.D.; Horton, E.S. Acute exercise increases the number of plasma membrane glucose transporters in rat skeletal muscle. FEBS Lett. 1988, 238, 235-239.

46. Goodyear, L.J.; Hirshman, M.F.; Knutson, S.M.; Horton, E.D.; Horton, E.S. Effect of exercise training on glucose homeostasis in normal and insulin-deficient diabetic rats. J. Appl. Physiol. 1988, 65, 844-851.

47. Hirshman, M.F.; Goodyear, L.J.; Horton, E.D.; Wardzala, L.J.; Horton, E.S. Exercise training increases GLUT-4 protein in rat adipose cells. Am. J. Physiol. 1993, 264, E882-889.

48. Wallberg-Henriksson, H. Repeated exercise regulates glucose transport capacity in skeletal muscle. Acta Physiol. Scand. 1986, 127, 39-43.

49. Cartee, G.D.; Young, D.A.; Sleeper, M.D.; Zierath, J.; Wallberg-Henriksson, H.; Holloszy, J.O. Prolonged increase in insulin-stimulated glucose transport in muscle after exercise. Am. J. Physiol. 1989, 256, E494-499.

50. Wallberg-Henriksson, H.; Constable, S.H.; Young, D.A.; Holloszy, J.O. Glucose transport into rat skeletal muscle: interaction between exercise and insulin. J. Appl. Physiol. 1988, 65, 909-913.

51. Soman, V.R.; Koivisto, V.A.; Deibert, D.; Felig, P.; DeFronzo, R.A. Increased insulin sensitivity and insulin binding to monocytes after physical training. N. Engl. J. Med. 1979, 301, 1200-1204.

52. Bouchard, C.; Tremblay, A.; Despres, J.P.; Theriault, G.; Nadeau, A.; Lupien, P.J.; Moorjani, S.; Prudhomme, D.; Fournier, G. The response to exercise with constant energy intake in identical twins. Obes. Res. 1994, 2, 400-410.

53. Despres, J.P.; Pouliot, M.C.; Moorjani, S.; Nadeau, A.; Tremblay, A.; Lupien, P.J.; Theriault, G.; Bouchard, C. Loss of abdominal fat and metabolic response to exercise training in obese women. Am. J. Physiol. 1991, 261, E159-167.

54. Ross, R.; Dagnone, D.; Jones, P.J.; Smith, H.; Paddags, A.; Hudson, R.; Janssen, I. Reduction in obesity and related comorbid conditions after diet-induced weight loss or exercise-induced weight loss in men. A randomized, controlled trial. Ann. Intern. Med. 2000, 133, 92-103.

55. Ross, R.; Janssen, I. Is abdominal fat preferentially reduced in response to exercise-induced weight loss? Med. Sci. Sports Exerc. 1999, 31, S568-572.

56. Arakawa, K. Hypertension and exercise. Clin. Exp. Hypertens 1993, 15, 1171-1179.

57. Reid, C.M.; Dart, A.M.; Dewar, E.M.; Jennings, G.L. Interactions between the effects of exercise and weight loss on risk factors, cardiovascular haemodynamics and left ventricular structure in overweight subjects. J. Hypertens 1994, 12, 291-301.

58. DeFronzo, R.A. Insulin and renal sodium handling: clinical implications. Int. J. Obes. 1981, 5, 93-104.

59. Reaven, G.M.; Hoffman, B.B. A role for insulin in the aetiology and course of hypertension? Lancet 1987, 2, 435-437.

60. Rowe, J.W.; Young, J.B.; Minaker, K.L.; Stevens, A.L.; Pallotta, J.; Landsberg, L. Effect of insulin and glucose infusions on sympathetic nervous system activity in normal man. Diabetes 1981, 30, 219-225.

61. Kanai, H.; Tokunaga, K.; Fujioka, S.; Yamashita, S.; Kameda-Takemura, K.K.; Matsuzawa, Y. Decrease in intra-abdominal visceral fat may reduce blood pressure in obese hypertensive women. Hypertension 1996, 27, 125-129. 
62. Powell, K.E.; Thompson, P.D.; Caspersen, C.J.; Kendrick, J.S. Physical activity and the incidence of coronary heart disease. Annu. Rev. Public Health 1987, 8, 253-287.

63. Pereira, M.A.; Jacobs, D.R., Jr.; Pins, J.J.; Raatz, S.K.; Gross, M.D.; Slavin, J.L.; Seaquist, E.R. Effect of whole grains on insulin sensitivity in overweight hyperinsulinemic adults. Am. J. Clin. Nutr. 2002, 75, 848-855.

64. Appel, L.J.; Moore, T.J.; Obarzanek, E.; Vollmer, W.M.; Svetkey, L.P.; Sacks, F.M.; Bray, G.A.; Vogt, T.M.; Cutler, J.A.; Windhauser, M.M.; Lin, P.H.; Karanja, N. A clinical trial of the effects of dietary patterns on blood pressure. DASH Collaborative Research Group. N. Engl. J. Med. 1997, 336, 1117-1124.

65. Jenkins, D.J.; Kendall, C.W.; Marchie, A.; Faulkner, D.A.; Wong, J.M.; de Souza, R.; Emam, A.; Parker, T.L.; Vidgen, E.; Lapsley, K.G.; Trautwein, E.A.; Josse, R.G.; Leiter, L.A.; Connelly, P.W. Effects of a dietary portfolio of cholesterol-lowering foods vs lovastatin on serum lipids and C-reactive protein. JAMA 2003, 290, 502-510.

66. Hung, T.; Sievenpiper, J.L.; Marchie, A.; Kendall, C.W.; Jenkins, D.J. Fat versus carbohydrate in insulin resistance, obesity, diabetes and cardiovascular disease. Curr. Opin. Clin. Nutr. Metab. Care 2003, 6, 165-176.

67. Hu, F.B.; van Dam, R.M.; Liu, S. Diet and risk of Type II diabetes: the role of types of fat and carbohydrate. Diabetologia 2001, 44, 805-817.

68. Meyer, K.A.; Kushi, L.H.; Jacobs, D.R., Jr.; Folsom, A.R. Dietary fat and incidence of type 2 diabetes in older Iowa women. Diabetes Care 2001, 24, 1528-1535.

69. Rosholt, M.N.; King, P.A.; Horton, E.S. High-fat diet reduces glucose transporter responses to both insulin and exercise. Am. J. Physiol. 1994, 266, R95-101.

70. Rosenberg Zand, R.S.; Grass, L.; Magklara, A.; Jenkins, D.J.; Diamandis, E.P. Is ICI 182,780 an antiprogestin in addition to being an antiestrogen? Breast Cancer Res. Treat 2000, 60, 1-8.

71. Jacobs, D.R., Jr.; Marquart, L.; Slavin, J.; Kushi, L.H. Whole-grain intake and cancer: an expanded review and meta-analysis. Nutr. Cancer 1998, 30, 85-96.

72. Jacobs, D.R., Jr.; Meyer, K.A.; Kushi, L.H.; Folsom, A.R. Whole-grain intake may reduce the risk of ischemic heart disease death in postmenopausal women: the Iowa Women's Health Study. Am. J. Clin. Nutr. 1998, 68, 248-257.

73. Jacobs, D.R., Jr.; Meyer, K.A.; Kushi, L.H.; Folsom, A.R. Is whole grain intake associated with reduced total and cause-specific death rates in older women? The Iowa women's health study. Am. J. Public Health 1999, 89, 322-329.

74. Jacobs, D.R.; Pereira, M.; Slavin, J.; Marquart, L. Defining the impact of whole grain intake on chronic desease. Cereal Foods World 2000, 45, 51-53.

75. Jacobs, D.R., Jr.; Steffen, L.M. Nutrients, foods, and dietary patterns as exposures in research: a framework for food synergy. Am. J. Clin. Nutr. 2003, 78, 508S-513S.

76. Pereira, M.A.; Jacobs, D.J.; Pins, J.J.; Marquart, L.; Keenan, J. Whole grains, cereal fiber, and chronic disease: The epidemiologic evidence. In CRC Handbook of Dietary Fiber in Human Disease; 3rd ed.; Spiller, G.A., Ed.; CRC Press: New York, NY, USA, 2001; pp. 481-498.

77. Pereira, M.A.; Pins, J.J. Dietary fiber and cardiovascular disease: experimental and epidemiologic advances. Curr. Atheroscler Rep. 2000, 2, 494-502. 
78. Pereira, M.A.; Ludwig, D.S. Dietary fiber and body-weight regulation. Observations and mechanisms. Pediatr. Clin. North Am. 2001, 48, 969-980.

79. Pereira, M.A.; Liu, S. Types of carbohydrates and risk of cardiovascular disease. J. Womens Health (Larchmt) 2003, 12, 115-122.

80. Pins, J.J.; Pereira, M.A.; Jacobs, D.J.; Marquart, L.; Laving, J.E. Whole grains cereal fiber and chronic disease: Possible biological mechanisms. In CRC Handbook of Dietary Fiber in Human Disease; 3rd ed.; Spiller, G. A., Ed.; CRC Press: New York, NY, USA, 2001; pp. 481-498.

81. Ludwig, D.S. The glycemic index: physiological mechanisms relating to obesity, diabetes, and cardiovascular disease. JAMA 2002, 287, 2414-2423.

82. Ludwig, D.S.; Pereira, M.A.; Kroenke, C.H.; Hilner, J.E.; Van Horn, L.; Slattery, M.L.; Jacobs, D.R., Jr. Dietary fiber, weight gain, and cardiovascular disease risk factors in young adults. JAMA 1999, 282, 1539-1546.

83. Jenkins, A.L.; Jenkins, D.J. Dietary fibre, glycaemic index and diabetes. S. Afr. Med. J. 1994, 6, 36-37.

84. Jenkins, D.J.; Kendall, C.W.; Augustin, L.S.; Franceschi, S.; Hamidi, M.; Marchie, A.; Jenkins, A.L.; Axelsen, M. Glycemic index: overview of implications in health and disease. Am. J. Clin. Nutr. 2002, 76, 266S-273S.

85. Jenkins, D.J.; Kendall, C.W.; Axelsen, M.; Augustin, L.S.; Vuksan, V. Viscous and nonviscous fibres, nonabsorbable and low glycaemic index carbohydrates, blood lipids and coronary heart disease. Curr. Opin. Lipidol. 2000, 11, 49-56.

86. Jenkins, D.J.; Kendall, C.W.; Marchie, A.; Parker, T.L.; Connelly, P.W.; Qian, W.; Haight, J.S.; Faulkner, D.; Vidgen, E.; Lapsley, K.G.; Spiller, G.A. Dose response of almonds on coronary heart disease risk factors: blood lipids, oxidized low-density lipoproteins, lipoprotein(a), homocysteine, and pulmonary nitric oxide: a randomized, controlled, crossover trial. Circulation 2002, 106, 1327-1332.

87. Jenkins, D.J.; Kendall, C.W.; Mehling, C.C.; Parker, T.; Rao, A.V.; Agarwal, S.; Novokmet, R.; Jones, P.J.; Raeini, M.; Story, J.A.; Furumoto, E.; Vidgen, E.; Griffin, L.C.; Cunnane, S.C.; Ryan, M.A.; Connelly, P.W. Combined effect of vegetable protein (soy) and soluble fiber added to a standard cholesterol-lowering diet. Metabolism 1999, 48, 809-816.

88. Jenkins, D.J.; Kendall, C.W.; Popovich, D.G.; Vidgen, E.; Mehling, C.C.; Vuksan, V.; Ransom, T.P.; Rao, A.V.; Rosenberg-Zand, R.; Tariq, N.; Corey, P.; Jones, P.J.; Raeini, M.; Story, J.A.; Furumoto, E.J.; Illingworth, D.R.; Pappu, A.S.; Connelly, P.W. Effect of a very-high-fiber vegetable, fruit, and nut diet on serum lipids and colonic function. Metabolism 2001, 50, 494-503.

89. Jenkins, D.J.; Popovich, D.G.; Kendall, C.W.; Vidgen, E.; Tariq, N.; Ransom, T.P.; Wolever, T.M.; Vuksan, V.; Mehling, C.C.; Boctor, D.L.; Bolognesi, C.; Huang, J.; Patten, R. Effect of a diet high in vegetables, fruit, and nuts on serum lipids. Metabolism 1997, 46, 530-537.

90. Wolever, T.M.; Mehling, C. High-carbohydrate-low-glycaemic index dietary advice improves glucose disposition index in subjects with impaired glucose tolerance. Br. J. Nutr. 2002, 87, 477-487.

91. Wolever, T.M. Dietary carbohydrates and insulin action in humans. Br. J. Nutr. 2000, 83, S97-102. 
92. Wolever, T.M. Carbohydrate and the regulation of blood glucose and metabolism. Nutr. Rev. 2003, 61, S40-48.

93. Wolever, T.M. The glycemic index: flogging a dead horse? Diabetes Care 1997, 20, 452-456.

94. Fukagawa, N.K.; Anderson, J.W.; Hageman, G.; Young, V.R.; Minaker, K.L. High-carbohydrate, high-fiber diets increase peripheral insulin sensitivity in healthy young and old adults. Am. J. Clin. Nutr. 1990, 52, 524-528.

95. Chandalia, M.; Garg, A.; Lutjohann, D.; von Bergmann, K.; Grundy, S.M.; Brinkley, L.J. Beneficial effects of high dietary fiber intake in patients with type 2 diabetes mellitus. N. Engl. J. Med. 2000, 342, 1392-1398.

96. Frost, G.; Leeds, A.; Trew, G.; Margara, R.; Dornhorst, A. Insulin sensitivity in women at risk of coronary heart disease and the effect of a low glycemic diet. Metabolism 1998, 47, 1245-1251.

97. Frost, G.; Keogh, B.; Smith, D.; Akinsanya, K.; Leeds, A. The effect of low-glycemic carbohydrate on insulin and glucose response in vivo and in vitro in patients with coronary heart disease. Metabolism 1996, 45, 669-672.

98. Chlebowski, R.T.; Blackburn, G.L.; Buzzard, I.M.; Rose, D.P.; Martino, S.; Khandekar, J.D.; York, R.M.; Jeffery, R.W.; Elashoff, R.M.; Wynder, E.L. Adherence to a dietary fat intake reduction program in postmenopausal women receiving therapy for early breast cancer. The Women's Intervention Nutrition Study. J. Clin. Oncol. 1993, 11, 2072-2080.

99. Jenkins, D.J.; Axelsen, M.; Kendall, C.W.; Augustin, L.S.; Vuksan, V.; Smith, U. Dietary fibre, lente carbohydrates and the insulin-resistant diseases. Br. J. Nutr. 2000, 83, S157-163.

100. Jenkins, D.J.; Jenkins, A.L.; Wolever, T.M.; Rao, A.V.; Thompson, L.U. Fiber and starchy foods: gut function and implications in disease. Am. J. Gastroenterol. 1986, 81, 920-930.

101. Jenkins, D.J.; Jenkins, A.L.; Wolever, T.M.; Vuksan, V.; Rao, A.V.; Thompson, L.U.; Josse, R.G. Effect of reduced rate of carbohydrate absorption on carbohydrate and lipid metabolism. Eur. J. Clin. Nutr. 1995, 49, S68-73.

102. Ludwig, D.S. Dietary glycemic index and obesity. J. Nutr. 2000, 130, 280S-283S.

103. Pereira, M.A.; Ebbeling, C.B.; Pawlak, D.B.; Leidig, M.M.; Ludwig, D.S. Whole grain consumption and body weight regulation. In Whole grain foods in health and disease; Marquart, L., Slavin, J.L., Fulcher, R.G., Eds.; American Association of Cereal Chemists: St. Paul, MN, USA, 2002; pp. 233-242.

104.Zock, P.L.; Katan, M.B.; Mensink, R.P. Dietary trans fatty acids and lipoprotein cholesterol. Am. J. Clin. Nutr. 1995, 61, 617.

105.Hu, F.B.; Manson, J.E.; Willett, W.C. Types of dietary fat and risk of coronary heart disease: a critical review. J. Am. Coll. Nutr. 2001, 20, 5-19.

106. Hu, F.B.; Stampfer, M.J.; Manson, J.E.; Rimm, E.; Colditz, G.A.; Rosner, B.A.; Hennekens, C.H.; Willett, W.C. Dietary fat intake and the risk of coronary heart disease in women. N. Engl. J. Med. 1997, 337, 1491-1499.

107. Fraser, G.E.; Sabate, J.; Beeson, W.L.; Strahan, T.M. A possible protective effect of nut consumption on risk of coronary heart disease. The Adventist Health Study. Arch. Intern. Med. 1992, 152, 1416-1424.

108. Sabate, J. Does nut consumption protect against ischaemic heart disease? Eur. J. Clin. Nutr. 1993, $47, \mathrm{~S} 71-75$. 
109. Sabate, J. Nut consumption, vegetarian diets, ischemic heart disease risk, and all-cause mortality: evidence from epidemiologic studies. Am. J. Clin. Nutr. 1999, 70, 500S-503S.

110. Hu, F.B.; Stampfer, M.J. Nut consumption and risk of coronary heart disease: a review of epidemiologic evidence. Curr. Atheroscler Rep. 1999, 1, 204-209.

111.Hu, F.B.; Stampfer, M.J.; Manson, J.E.; Rimm, E.B.; Colditz, G.A.; Rosner, B.A.; Speizer, F.E.; Hennekens, C.H.; Willett, W.C. Frequent nut consumption and risk of coronary heart disease in women: prospective cohort study. BMJ 1998, 317, 1341-1345.

112. Mensink, R.P.; Zock, P.L.; Kester, A.D.; Katan, M.B. Effects of dietary fatty acids and carbohydrates on the ratio of serum total to HDL cholesterol and on serum lipids and apolipoproteins: a meta-analysis of 60 controlled trials. Am. J. Clin. Nutr. 2003, 77, 1146-1155.

113. Jeppesen, J.; Schaaf, P.; Jones, C.; Zhou, M.Y.; Chen, Y.D.; Reaven, G.M. Effects of low-fat, high-carbohydrate diets on risk factors for ischemic heart disease in postmenopausal women. Am. J. Clin. Nutr. 1997, 65, 1027-1033.

114. Chen, Y.D.; Coulston, A.M.; Zhou, M.Y.; Hollenbeck, C.B.; Reaven, G.M. Why do low-fat highcarbohydrate diets accentuate postprandial lipemia in patients with NIDDM? Diabetes Care 1995, $18,10-16$.

115. Katan, M.B.; Zock, P.L.; Mensink, R. P. Effects of fats and fatty acids on blood lipids in humans: an overview. Am. J. Clin. Nutr. 1994, 60, 1017S-1022S.

116. Katan, M.B.; Mensink, R.; Van Tol, A.; Zock, P.L. Dietary trans fatty acids and their impact on plasma lipoproteins. Can. J. Cardiol. 1995, 11, 36G-38G.

117. Mensink, R.P.; Katan, M.B. Trans monounsaturated fatty acids in nutrition and their impact on serum lipoprotein levels in man. Prog. Lipid. Res. 1993, 32, 111-122.

118. Mensink, R.P.; Zock, P.L.; Katan, M.B.; Hornstra, G. Effect of dietary cis and trans fatty acids on serum lipoprotein[a] levels in humans. J. Lipid. Res. 1992, 33, 1493-1501.

119. Sacks, F.M.; Obarzanek, E.; Windhauser, M.M.; Svetkey, L.P.; Vollmer, W.M.; McCullough, M.; Karanja, N.; Lin, P.H.; Steele, P.; Proschan, M.A. Rationale and design of the Dietary Approaches to Stop Hypertension trial (DASH). A multicenter controlled-feeding study of dietary patterns to lower blood pressure. Ann. Epidemiol. 1995, 5, 108-118.

120. Sacks, F.M.; Kass, E.H. Low blood pressure in vegetarians: effects of specific foods and nutrients. Am. J. Clin. Nutr. 1988, 48, 795-800.

121. Verdaet, D.; Dendale, P.; De Bacquer, D.; Delanghe, J.; Block, P.; De Backer, G. Association between leisure time physical activity and markers of chronic inflammation related to coronary heart disease. Atherosclerosis 2004, 176, 303-310.

122. Abramson, J.L.; Vaccarino, V. Relationship between physical activity and inflammation among apparently healthy middle-aged and older US adults. Arch. Intern. Med. 2002, 162, 1286-1292.

123. Geffken, D.F.; Cushman, M.; Burke, G.L.; Polak, J.F.; Sakkinen, P.A.; Tracy, R.P. Association between physical activity and markers of inflammation in a healthy elderly population. Am. J. Epidemiol. 2001, 153, 242-250.

124. Ford, E.S. Does exercise reduce inflammation? Physical activity and C-reactive protein among U.S. adults. Epidemiology 2002, 13, 561-568. 
125. Lakka, T.A.; Laaksonen, D.E.; Lakka, H.M.; Mannikko, N.; Niskanen, L.K.; Rauramaa, R.; Salonen, J.T. Sedentary lifestyle, poor cardiorespiratory fitness, and the metabolic syndrome. Med. Sci. Sports Exerc. 2003, 35, 1279-1286.

126. Laaksonen, D.E.; Lakka, H.M.; Salonen, J.T.; Niskanen, L.K.; Rauramaa, R.; Lakka, T.A. Low levels of leisure-time physical activity and cardiorespiratory fitness predict development of the metabolic syndrome. Diabetes Care 2002, 25, 1612-1618.

127. McKeown, N.M.; Meigs, J.B.; Liu, S.; Saltzman, E.; Wilson, P.W.; Jacques, P.F. Carbohydrate nutrition, insulin resistance, and the prevalence of the metabolic syndrome in the Framingham Offspring Cohort. Diabetes Care 2004, 27, 538-546.

128. Wirfalt, E.; Hedblad, B.; Gullberg, B.; Mattisson, I.; Andren, C.; Rosander, U.; Janzon, L.; Berglund, G. Food patterns and components of the metabolic syndrome in men and women: a cross-sectional study within the Malmo Diet and Cancer cohort. Am. J. Epidemiol. 2001, 154, 1150-1159.

129. Pereira, M.A.; Kartashov, A.I.; Ebbeling, C.B.; Van Horn, L.; Slattery, M.L.; Jacobs, D.R., Jr,; Ludwig, D.S. Fast food habits, weight gain, and insulin resistance in a 15 -year prospective analysis of The CARDIA Study. Lancet (In press).

130. Pereira, M.A.; Jacobs, D.R., Jr.; Van Horn, L.; Slattery, M.L.; Kartashov, A.I.; Ludwig, D.S. Dairy consumption, obesity, and the insulin resistance syndrome in young adults: the CARDIA Study. JAMA 2002, 287, 2081-2089.

131. Torjesen, P.A.; Birkeland, K.I.; Anderssen, S.A.; Hjermann, I.; Holme, I.; Urdal, P. Lifestyle changes may reverse development of the insulin resistance syndrome. The oslo diet and exercise study: a randomized trial. Diabetes Care 1997, 20, 26-31.

132. Anderssen, S.A.; Hjermann, I.; Urdal, P.; Torjesen, P.A.; Holme, I. Improved carbohydrate metabolism after physical training and dietary intervention in individuals with the "atherothrombogenic syndrome". Oslo Diet and Exercise Study (ODES). A randomized trial. $J$. Intern. Med. 1996, 240, 203-209.

133. Esposito, K.; Marfella, R.; Ciotola, M.; Di Palo, C.; Giugliano, F.; Giugliano, G.; D'Armiento, M.; D'Andrea, F.; Giugliano, D. Effect of a mediterranean-style diet on endothelial dysfunction and markers of vascular inflammation in the metabolic syndrome: a randomized trial. JAMA 2004, 292, 1440-1446.

134. Eriksson, K.F.; Lindgarde, F. Prevention of type 2 (non-insulin-dependent) diabetes mellitus by diet and physical exercise. The 6-year Malmo feasibility study. Diabetologia 1991, 34, 891-898.

135. Knowler, W.C.; Barrett-Connor, E.; Fowler, S.E.; Hamman, R.F.; Lachin, J.M.; Walker, E.A.; Nathan, D.M. Reduction in the incidence of type 2 diabetes with lifestyle intervention or metformin. N. Engl. J. Med. 2002, 346, 393-403.

136. Tuomilehto, J.; Lindstrom, J.; Eriksson, J.G.; Valle, T.T.; Hamalainen, H.; Ilanne-Parikka, P.; Keinanen-Kiukaanniemi, S.; Laakso, M.; Louheranta, A.; Rastas, M.; Salminen, V.; Uusitupa, M. Prevention of type 2 diabetes mellitus by changes in lifestyle among subjects with impaired glucose tolerance. N. Engl. J. Med. 2001, 344, 1343-1350. 
137.Pan, X.R.; Li, G.W.; Hu, Y.H.; Wang, J.X.; Yang, W.Y.; An, Z.X.; Hu, Z.X.; Lin, J.; Xiao, J.Z.; Cao, H.B.; Liu, P.A.; Jiang, X.G.; Jiang, Y.Y.; Wang, J.P.; Zheng, H.; Zhang, H.; Bennett, P.H.; Howard, B.V. Effects of diet and exercise in preventing NIDDM in people with impaired glucose tolerance. The Da Qing IGT and Diabetes Study. Diabetes Care 1997, 20, 537-544.

138. Franz, M.J.; van Wormer, J.J.; Crain, A.L.; Boucher, J.L.; Histon, T.; Caplan, W.; Bowman, J.D.; Pronk, N.P. Weight-Loss Outcomes: A Systematic Review and Meta-Analysis of Weight-Loss Clinical Trials with a Minimum 1-Year Follow-Up. J. Am. Dietetic Assn. 2007, 107, 1755-1767.

139. U.S. Preventive Services Task Force. Physical Activity Counseling. Available online: http://www.ahrq.gov/clinic/uspstf/uspsphys.htm (accessed August 10, 2009).

140. Pignone, M.P.; Ammerman, A.; Fernandez, L.; Orleans, C.T.; Pender, N.; Woolf, S.; Lohr, K.N.; Sutton, S. Counseling to promote a healthy diet in adults: a summary of the evidence for the U.S. Preventive Services Task Force. Am. J. Prev. Med. 2003, 24, 75-92.

141. Laatikainen, T.; Critchley, J.; Vartiainen, E.; Salomaa, V.; Ketonen, M.; Capewell, S. Explaining the decline in coronary heart disease mortality in Finland between 1982 and 1997. Am. J. Epidemiol. 2005, 162, 764-773.

142. Jordan, C.O.; Slatter, M.; Kottke, T.E. Preventing chronic disease risk factors: rationale and feasibility. Medicina (Kaunas) 2008, 44, 745-750.

143. Thygeson, N.M.; Gallagher, J.; Cross, K.; Pronk, N.P. Employee health at BAE Systems: An employer-health plan partnership approach. In ACSM's Worksite Health Handbook, Second Edition, A Guide to Building Healthy and Productive Companies.; Pronk, N.P., Ed.; Human Kinetics: Champaign, IL, USA, 2009.

144. Kahn, R.; Buse, J.; Ferrannini, E.; Stern, M. The metabolic syndrome: time for a critical appraisal: joint statement from the American Diabetes Association and the European Association for the Study of Diabetes. Diabetes Care 2005, 28, 2289-2304.

145. Fraser, G.E.; Shavlik, D.J. Ten years of life: Is it a matter of choice? Arch. Intern. Med. 2001, $161,1645-1652$.

146. Khaw, K.-T.; Wareham, N.; Bingham, S.; Welch, A.; Luben, R.; Day, N. Combined Impact of Health Behaviours and Mortality in Men and Women: The EPIC-Norfolk Prospective Population Study PLoS Med. 2008, 5, e12.

147. Lloyd-Jones, D.M.; Liu, K.; Tian, L.; Greenland, P. Narrative Review: Assessment of C-Reactive Protein in Risk Prediction for Cardiovascular Disease. Ann. Intern. Med. 2006.

148. Folsom, A.R.; Pankow, J.S.; Tracy, R.P.; Arnett, D.K.; Peacock, J.M.; Hong, Y.; Djousse, L.; Eckfeldt, J.H. Association of C-reactive protein with markers of prevalent atherosclerotic disease. Am. J. Cardiol. 2001, 88, 112-117.

149. Klein, S.; Allison, D.B.; Heymsfield, S.B.; Kelley, D.E.; Leibel, R.L.; Nonas, C.; Kahn, R. Waist circumference and cardiometabolic risk: a consensus statement from shaping America's health: Association for Weight Management and Obesity Prevention; NAASO, the Obesity Society; the American Society for Nutrition; and the American Diabetes Association. Diabetes Care 2007, 30, 1647-1652.

150. Babor, T.F.; Sciamanna, C.N.; Pronk, N.P. Assessing multiple risk behaviors in primary care. Screening issues and related concepts. Am. J. Prev. Med. 2004, 27, 42-53. 
151. Kottke, T.E.; Jordan, C.O.; O'Connor, P.J.; Pronk, N.P.; Carreon, R. Readiness of US health plans to manage cardiometabolic risk. Prev. Chronic Dis. 2009, 6, A85.

(C) 2009 by the authors; licensee Molecular Diversity Preservation International, Basel, Switzerland. This article is an open-access article distributed under the terms and conditions of the Creative Commons Attribution license (http://creativecommons.org/licenses/by/3.0/). 